Article

\title{
Atypical Ductal Hyperplasia after Vacuum-Assisted Breast Biopsy: Can We Reduce the Upgrade to Breast Cancer to an Acceptable Rate?
}

\author{
Luca Nicosia ${ }^{1}$, Antuono Latronico ${ }^{1}$, Francesca Addante ${ }^{2}$, Rossella De Santis ${ }^{3}$, Anna Carla Bozzini ${ }^{1}$, \\ Marta Montesano ${ }^{1}$, Samuele Frassoni ${ }^{4}$, Vincenzo Bagnardi ${ }^{4}$, Giovanni Mazzarol ${ }^{5}$, Oriana Pala ${ }^{5}$, \\ Matteo Lazzeroni ${ }^{6}$ (D), Germana Lissidini ${ }^{7}$, Mauro Giuseppe Mastropasqua ${ }^{2, *}{ }^{(1)}$ and Enrico Cassano ${ }^{1}$
}

check for updates

Citation: Nicosia, L.; Latronico, A.; Addante, F.; De Santis, R.; Bozzini, A.C.; Montesano, M.; Frassoni, S.; Bagnardi, V.; Mazzarol, G.; Pala, O.; et al. Atypical Ductal Hyperplasia after Vacuum-Assisted Breast Biopsy: Can We Reduce the Upgrade to Breast Cancer to an Acceptable Rate? Diagnostics 2021, 11, 1120. https://doi.org/10.3390/ diagnostics11061120

Academic Editor:

Gustavo Baldassarre

Received: 2 May 2021

Accepted: 17 June 2021

Published: 19 June 2021

Publisher's Note: MDPI stays neutral with regard to jurisdictional claims in published maps and institutional affiliations.

Copyright: (c) 2021 by the authors Licensee MDPI, Basel, Switzerland. This article is an open access article distributed under the terms and conditions of the Creative Commons Attribution (CC BY) license (https:// creativecommons.org/licenses/by/ $4.0 /)$.
1 Department of Breast Radiology, IEO European Institute of Oncology, IRCCS, 20141 Milan, Italy; luca.nicosia@ieo.it (L.N.); antuono.latronico@ieo.it (A.L.); anna.bozzini@ieo.it (A.C.B.); marta.montesano@ieo.it (M.M.); enrico.cassano@ieo.it (E.C.)

2 Department of Emergency and Organ Transplantation, Section of Anatomic Pathology, School of Medicine, University "Aldo Moro", 70124 Bari, Italy; francesca.addante1@gmail.com

3 Postgraduate School in Radiology, University of Milan, 20122 Milan, Italy; rossella.desantis@unimi.it

4 Department of Statistics and Quantitative Methods, University of Milan-Bicocca, 20126 Milan, Italy; samuele.frassoni@unimib.it (S.F.); vincenzo.bagnardi@unimib.it (V.B.)

5 Division of Pathology and Laboratory Medicine, IEO European Institute of Oncology, IRCCS, 20141 Milan, Italy; giovanni.mazzarol@ieo.it (G.M.); oriana.pala@ieo.it (O.P.)

6 Division of Cancer Prevention and Genetics, IEO European Institute of Oncology IRCCS, 20141 Milan, Italy; matteo.lazzeroni@ieo.it

7 Division of Breast Surgery, IEO European Institute of Oncology, IRCCS, 20141 Milan, Italy; germana.lissidini@ieo.it

* Correspondence: mauro.mastropasqua@uniba.it; Tel.: +39-0805594414

\begin{abstract}
Background: to evaluate which factors can reduce the upgrade rate of atypical ductal hyperplasia $(\mathrm{ADH})$ to in situ or invasive carcinoma in patients who underwent vacuum-assisted breast biopsy (VABB) and subsequent surgical excision. (2) Methods: 2955 VABBs were reviewed; 141 patients with a diagnosis of $\mathrm{ADH}$ were selected for subsequent surgical excision. The association between patients' characteristics and the upgrade rate to breast cancer was evaluated in both univariate and multivariate analyses. (3) Results: the upgrade rates to ductal carcinoma in situ (DCIS) and invasive carcinoma (IC) were, respectively, $29.1 \%$ and $7.8 \%$. The pooled upgrade rate to DCIS or IC was statistically lower at univariate analysis, considering the following parameters: complete removal of the lesion ( $p$-value $<0.001)$; BIRADS $\leq 4 \mathrm{a}(p$-value $<0.001)$; size of the lesion $\leq 15 \mathrm{~mm}$ ( $p$-value: 0.002$)$; age of the patients $<50$ years ( $p$-value: 0.035$)$. (4) Conclusions: the overall upgrade rate of $\mathrm{ADH}$ to DCIS or IC is high and, as already known, surgery should be recommended. However, $\mathrm{ADH}$ cases should always be discussed in multidisciplinary meetings: some parameters appear to be related to a lower upgrade rate. Patients presenting these parameters could be strictly followed up to avoid overtreatment.
\end{abstract}

Keywords: breast biopsy; BIRADS; atypical duct hyperplasia; breast surgery; breast cancer; upgrade to cancer; overtreatment

\section{Introduction}

Breast lesions classified as having uncertain malignant potential (B3) on biopsy cause management challenges. Diagnostic improvement in the identification of breast lesions, together with the introduction of population-based mammographic screening programs, has led to an increased rate of B3 diagnoses. Atypical ductal hyperplasia (ADH) is one of the most frequent lesions observed. Mammographically detectable microcalcifications are typically associated [1]. ADH is morphologically defined as an epithelial intraductal proliferation with cytological and architectural features similar to those of low-grade ductal 
carcinoma in situ (DCIS), but with partial involvement of ducts and/or limited extension. ADH can exhibit different growth patterns (cribriform, micropapillary or solid) reaching up to $2 \mathrm{~mm}$ and is found in approximatively $1-10 \%$ of breast biopsies [1-4]. (Figure 1).

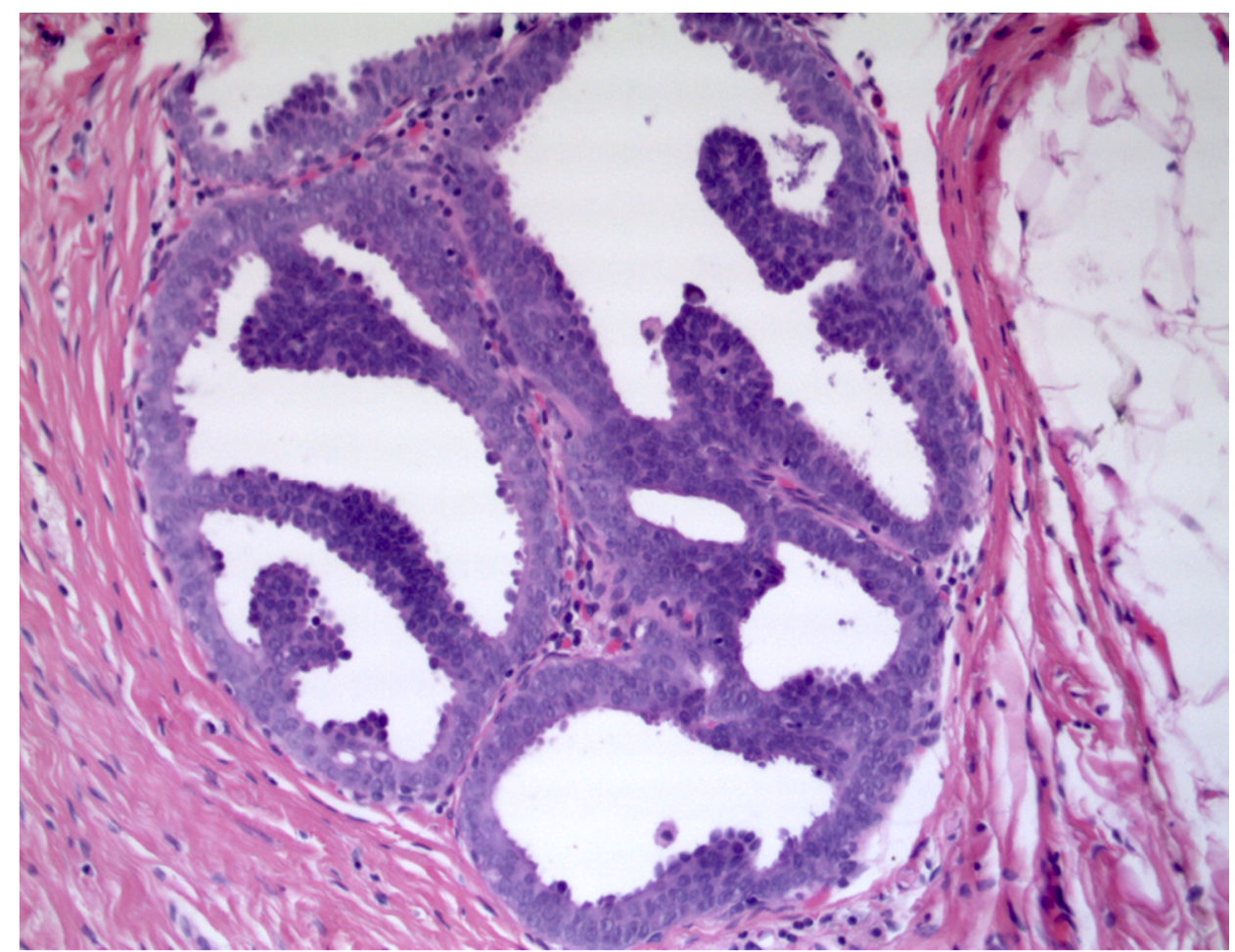

Figure 1. Atypical ductal hyperplasia with cribriform and micropapillary growth pattern (Hematoxylin \& Eosin, $400 \times)$.

A review of the available literature shows that $\mathrm{ADH}$ is often associated with a significantly higher risk of concomitant DCIS and/or invasive carcinoma (IC) diagnosed by subsequent surgical excisions [5-9]. Although debate on this subject still exists, the diagnosis of ADH is an indication for surgery [3,6,10-14].

According to the Second International Consensus Conference on breast lesions of uncertain malignant potential [15], with the exception of $\mathrm{ADH}$, minimally invasive management of B3 lesions with vacuum-assisted breast biopsy (VABB) continues to be an appropriate alternative to surgery in most cases. Conversely, ADH surgical excision is still recommended.

Follow up, without surgical excision, is infrequent and justified only in certain circumstances after multidisciplinary discussion. This may be due to the high percentage of biopsy-proven ADH lesions that are upgraded after subsequent surgical excision. The reported percentage of upgrade to DCIS and/or IC at the surgical excision after percutaneous breast biopsy is extremely variable in the literature, with values reaching up to $85 \%$ [16-19].

Clinical management of these lesions is based primarily on the risk of identifying carcinoma (either DCIS and/or IC) in the excision specimens [16-19]. In general, excision is usually recommended for $\mathrm{ADH}$.

The aim of this study is to evaluate which factors, especially radiological, can influence the upgrade rate of $\mathrm{ADH}$ to in situ or invasive carcinoma in a representative group of patients who underwent VABB and subsequent surgical excision.

The identification of factors associated with diagnostic underestimation can be of great help in selecting, after a multidisciplinary meeting, those patients in which follow-up may be recommended rather than surgical intervention, thus avoiding overtreatment. 
To reach this goal, we examined surgical specimens of patients diagnosed with ADH to identify potential indicators for upgrading.

\section{Materials and Methods}

We analyzed 2955 VABB performed at European Institute of Oncology (IEO, Milan, Italy) between January 2000 and December 2019 under ultrasound or stereotactic guidance. Of them, 141 were diagnosed as pure $\mathrm{ADH}$ lesions. All patients underwent subsequent surgical excision.

Lesions were classified according to the Breast Imaging Reporting and Data System (BI-RADS) [20].

The histological results of the biopsies were classified as B1 to B5 lesions, according to the UK B-coding system [21].

We selected lesions identified on mammograms or ultrasound as BI-RADS $\geq 3$.

Most cases (123/141) were identified with screening mammography and a stereotactic VABB was performed using an 11 or 8 Gauge $(G)$ needle.

In a few cases (18/141) lesion was identified during breast ultrasound performed for prevention in patients with dense breasts. In these cases, an ultrasound-guided biopsy was performed with a $10 \mathrm{G}$ needle.

All patients who underwent stereotactic breast biopsies had two projection mammograms before the procedure (Figure 2).

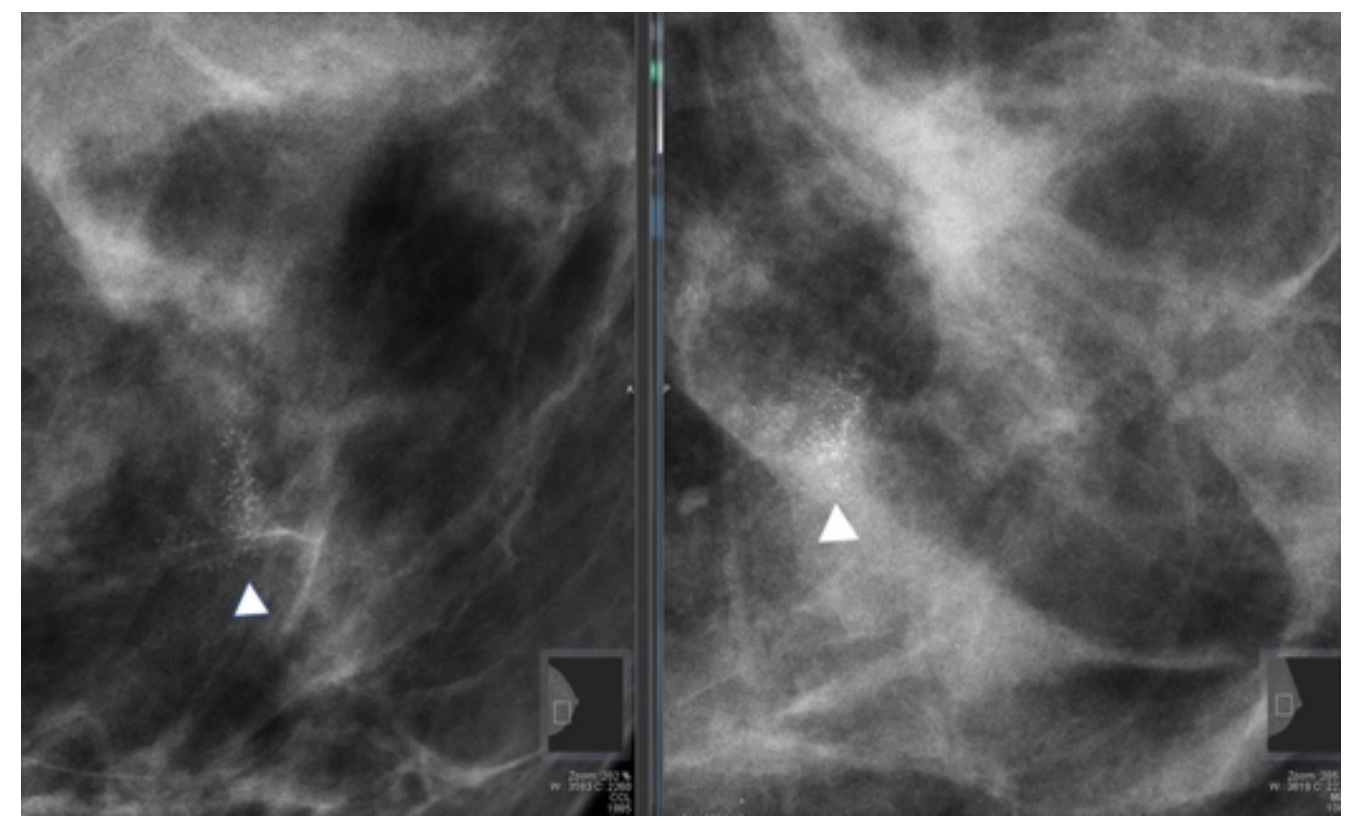

Figure 2. Full field digital mammography showing a cluster of microcalcifications (arrowhead) with a biopsy-proven histopathological result of atypical ductal hyperplasia.

The number of cores obtained for each biopsy was extracted from the pathological reports.

Following an ADH diagnosis of the biopsy specimen, surgical excision was performed in all patients.

The surgically obtained breast tissue specimens were grossly sampled following institutional guidelines. As a rule, surgical samples of patients who had previously undergone VABB were always $X$-rayed before gross examination to identify residual microcalcifications. Thereafter, the whole abnormal area, including residual adjacent fibrotic tissue, was paraffin-embedded and histologic sections were prepared and microscopically evaluated.

Each biopsy was individually compared with the corresponding excision specimen. In case of stereotactic VABB, all patients underwent two mammography projections after the biopsy in order to radiographically assess the complete removal of microcalcifications 
following the procedure. Analogously, in ultrasound-guided biopsies, an ultrasound scan was performed after the biopsy to assess the complete removal of the lesion following the procedure.

We evaluated the upgrade rate to breast cancer defined as the finding of a DCIS or IC in the surgical specimen.

We investigated a potential correlation between patient's age, lesion size, BIRADS, number of cores, complete macroscopic removal of the lesion, cases showing ADH only in cores bearing microcalcifications, and the chance of upgrade to DCIS or IC in the surgical specimen.

We also explored a possible correlation between these parameters and the absence of further lesions at the subsequent surgical excision, including those cases showing only benign findings in the excision specimen.

Finally, we evaluated patient follow-up to look for signs of recurrence defined as any patient developing histologically proven ipsilateral or contralateral breast lesion (classified as B3, B4 or B5) detected by periodic radiological examinations (performed after surgery for $\mathrm{ADH})$.

\section{Statistical Analysis}

Continuous data are reported as medians and interquartile ranges. Categorical data are reported as counts and percentages.

Fisher's exact test was performed to evaluate the association between patients' characteristics and the four different events (benign findings in the absence of $\mathrm{ADH}$ or further lesion at surgical excision, DCIS, IC and a combination of carcinoma in situ/invasive carcinoma).

A multivariate logistic regression model was performed to evaluate the association between a combined outcome (DCIS or IC) and the variables associated with the combined outcome in the univariate analysis.

Predicted probabilities of the combined outcome, according to the multivariate logistic regression model, were calculated.

The cumulative incidence of lesion curve functions was estimated using the KaplanMeier method. The log-rank test was used to assess differences between patients with or without upgrade to carcinoma in situ or invasive carcinoma. Univariable Cox proportional hazard regression models were used to assess the association between patients' characteristics and risk of lesion.

A $p$-value $\leq 0.05$ was considered statistically significant.

All analyses were performed with the statistical software SAS 9.4 (SAS Institute, Cary, NC, USA).

\section{Results}

Of the 2955 breast biopsies performed over a 20-year period, $141 \mathrm{ADH}$ cases were identified (the clinicopathological features of the patients are summarized in Table 1).

Of these, 123 were diagnosed by stereotactic biopsy and identified by mammography, while 18 cases were diagnosed by ultrasound-guided biopsy. Of the 123 stereotactic breast biopsies, all lesions were identified with mammography and showed only microcalcifications. The remaining 18 cases of our $\mathrm{ADH}$ population were detected as a nodule by ultrasound.

The median age of patients was 51 (45-59) years, the median number of cores per biopsy was 10 (8-13). The median size of the lesion was $15 \mathrm{~mm}(10-20 \mathrm{~mm})$.

Radiological diagnoses were 5 BIRADS $3(3.5 \%) ; 53$ BIRADS 4a (37.6\%); 52 BIRADS 4b (36.9\%); 29 BIRADS 4c (20.6\%); 2 BIRADS 5 (1.4\%). Overall, in 66/141 cases (47.8\%) the lesion (identified by mammography or ultrasound) was macroscopically removed by VABB.

On excision, considering all the 141 patients undergoing surgery, $11(7.8 \%)$ were upgraded to IC and $41(29.1 \%)$ were upgraded to DCIS. In detail, 31 out of $141(22 \%)$ cases were upgraded to low grade DCIS; 9 out of 141 (6.4\%) cases were upgraded to intermediate grade DCIS and 1 case $(0.7 \%)$ was upgraded to high grade DCIS. In $47 / 141(33.3 \%)$ cases, the diagnosis of ADH was confirmed in the surgical specimen. Conversely, in 42/141 (29.8\%) cases, $\mathrm{ADH}$ was not found in subsequent surgical specimens and only benign findings 
were observed. Apparently, in these cases the ADH focus had been completely removed with the VABB procedure.

The pooled upgrade rate to DCIS or IC was statistically lower (Table 2) at univariate analysis considering these parameters: the complete removal of the lesion $(p$-value $<0.001)$; BIRADS $\leq 4$ a ( $p$-value $<0.001)$; size of the lesion $\leq 15 \mathrm{~mm}$ ( $p$-value: 0.002$)$; age of the patients $<50$ years ( $p$-value: 0.035 ).

Table 1. Characteristics of patients $(\mathrm{N}=141)$.

\begin{tabular}{|c|c|}
\hline \multirow{2}{*}{ Variables } & \multirow{2}{*}{$\begin{array}{c}\text { Overall }(\mathrm{N}=141) \\
\mathrm{N}(\%)\end{array}$} \\
\hline & \\
\hline \multicolumn{2}{|l|}{ Age at biopsy (years) } \\
\hline$<40$ & $2(1.4)$ \\
\hline $40-49$ & $58(41.1)$ \\
\hline 50-59 & $50(35.5)$ \\
\hline $60-69$ & $22(15.6)$ \\
\hline $70+$ & $9(6.4)$ \\
\hline$<50$ & $60(42.6)$ \\
\hline $50+$ & 81 (57.4) \\
\hline Median (IQR) & $51(45-59)$ \\
\hline \multicolumn{2}{|l|}{ Days between biopsy and surgery } \\
\hline$\leq 30$ & $24(17.0)$ \\
\hline $31-60$ & $41(29.1)$ \\
\hline $61-90$ & $30(21.3)$ \\
\hline$>90$ & $46(32.6)$ \\
\hline Median (IQR) & $66(41-112)$ \\
\hline \multicolumn{2}{|l|}{ Size of the lesion $(\mathrm{mm})$} \\
\hline$\leq 15$ & $89(63.1)$ \\
\hline$>15$ & $52(36.9)$ \\
\hline Median (IQR) & $15(10-20)$ \\
\hline \multicolumn{2}{|l|}{ BIRADS classification of the lesion } \\
\hline 3 & $5(3.5)$ \\
\hline $4 a$ & $53(37.6)$ \\
\hline $4 b$ & $52(36.9)$ \\
\hline $4 c$ & $29(20.6)$ \\
\hline 5 & $2(1.4)$ \\
\hline $3-4 a$ & $58(41.1)$ \\
\hline $4 b-4 c-5$ & $83(58.9)$ \\
\hline \multicolumn{2}{|l|}{ Number of cores } \\
\hline$<10$ & $42(29.8)$ \\
\hline$\geq 10$ & $99(70.2)$ \\
\hline Median (IQR) & $10(8-13)$ \\
\hline \multicolumn{2}{|l|}{ Imaging findings } \\
\hline Microcalcifications & $123(87.2)$ \\
\hline Nodule & $17(12.1)$ \\
\hline Nodule with microcalcifications & $1(0.7)$ \\
\hline \multicolumn{2}{|l|}{ Residual lesion at the biopsy * } \\
\hline No & $66(47.8)$ \\
\hline Yes & $72(52.2)$ \\
\hline \multicolumn{2}{|c|}{ ADH only in cores with microcalcifications $\S$} \\
\hline No & $60(51.3)$ \\
\hline Yes & $57(48.7)$ \\
\hline
\end{tabular}

* 3 patients missing, ${ }^{\S} 24$ patients missing. 
Table 2. Association between patients' characteristics and four outcomes (univariate analysis).

\begin{tabular}{|c|c|c|c|c|c|c|c|c|}
\hline \multirow{3}{*}{ Variables } & \multirow[b]{2}{*}{$\begin{array}{l}\text { Confirmed } \\
\text { Diagnosis } \\
\text { of ADH }\end{array}$} & \multirow[b]{2}{*}{$\begin{array}{c}\text { Lesion } \\
\text { Removed }\end{array}$} & \multirow[b]{2}{*}{$\begin{array}{l}\text { Carcinoma } \\
\text { In Situ }\end{array}$} & \multirow[b]{2}{*}{$\begin{array}{l}\text { Invasive } \\
\text { Carci- } \\
\text { noma }\end{array}$} & \multicolumn{4}{|c|}{ Event Considered: } \\
\hline & & & & & $\begin{array}{c}\text { Lesion } \\
\text { Removed }\end{array}$ & $\begin{array}{l}\text { Carcinoma } \\
\text { In Situ }\end{array}$ & $\begin{array}{l}\text { Invasive } \\
\text { Carci- } \\
\text { noma }\end{array}$ & $\begin{array}{c}\text { Carcinoma } \\
\text { In Situ or } \\
\text { Invasive } \\
\text { Carcinoma }\end{array}$ \\
\hline & N (\%) & N (\%) & N (\%) & $\mathrm{N}(\%)$ & $p$-Value ${ }^{1}$ & $p$-Value ${ }^{1}$ & $p$-Value ${ }^{1}$ & $p$-Value ${ }^{1}$ \\
\hline Overall & $47(33.3)$ & $42(29.8)$ & $\begin{array}{c}41(29.1) \\
2\end{array}$ & $11(7.8)$ & & & & \\
\hline $\begin{array}{c}\text { Age at the biopsy (year) } \\
<50 \\
50+\end{array}$ & $\begin{array}{l}30(50.0) \\
17(21.0)\end{array}$ & $\begin{array}{l}14(23.3) \\
28(34.6)\end{array}$ & $\begin{array}{l}13(21.7) \\
28(34.6)\end{array}$ & $\begin{array}{l}3(5.0) \\
8(9.9)\end{array}$ & 0.19 & 0.086 & 0.21 & 0.035 \\
\hline $\begin{array}{c}\text { Size of the lesion }(\mathrm{mm}) \\
\leq 15 \\
>15\end{array}$ & $\begin{array}{l}34(38.2) \\
13(25.0)\end{array}$ & $\begin{array}{l}31(34.8) \\
11(21.2)\end{array}$ & $\begin{array}{l}18(20.2) \\
23(44.2)\end{array}$ & $\begin{array}{l}6(6.7) \\
5(9.6)\end{array}$ & 0.13 & 0.002 & 0.29 & 0.002 \\
\hline $\begin{array}{l}\text { BIRADS classification of } \\
\text { the lesion } \\
\quad 3-4 \mathrm{a} \\
4 \mathrm{~b}-4 \mathrm{c}-5\end{array}$ & $\begin{array}{l}22(37.9) \\
25(30.1)\end{array}$ & $\begin{array}{l}26(44.8) \\
16(19.3)\end{array}$ & $\begin{array}{c}8(13.8) \\
33(39.8)\end{array}$ & $\begin{array}{c}2(3.4) \\
9(10.8)\end{array}$ & 0.001 & $<0.001$ & 0.051 & $<0.001$ \\
\hline $\begin{array}{c}\text { Number of cores } \\
<10 \\
\geq 10\end{array}$ & $\begin{array}{l}16(38.1) \\
31(31.3)\end{array}$ & $\begin{array}{c}8(19.0) \\
34(34.3)\end{array}$ & $\begin{array}{l}15(35.7) \\
26(26.3)\end{array}$ & $\begin{array}{l}3(7.1) \\
8(8.1)\end{array}$ & 0.074 & 0.31 & 1.00 & 0.35 \\
\hline $\begin{array}{l}\text { Imaging findings } \\
\text { Microcalcifications } \\
\text { Nodule/Nodule with } \\
\text { microcalcifications }\end{array}$ & $\begin{array}{l}41(33.3) \\
6(33.3)\end{array}$ & $\begin{array}{c}39(31.7) \\
3(16.7)\end{array}$ & $\begin{array}{c}34(27.6) \\
7(38.9)\end{array}$ & $\begin{array}{c}9(7.3) \\
2(11.1)\end{array}$ & 0.27 & 0.27 & 0.35 & 0.30 \\
\hline $\begin{array}{l}\text { Residual lesion at biopsy }{ }^{3} \\
\text { No } \\
\text { Yes }\end{array}$ & $\begin{array}{l}22(33.3) \\
24(33.3)\end{array}$ & $\begin{array}{l}29(43.9) \\
11(15.3)\end{array}$ & $\begin{array}{l}11(16.7) \\
30(41.7)\end{array}$ & $\begin{array}{l}4(6.1) \\
7(9.7)\end{array}$ & $<0.001$ & $<0.001$ & 0.20 & $<0.001$ \\
\hline $\begin{array}{l}\text { ADH only in cores with } \\
\text { microcalcifications }{ }^{4} \\
\text { No } \\
\text { Yes }\end{array}$ & $\begin{array}{l}20(33.3) \\
19(33.3)\end{array}$ & $\begin{array}{l}16(26.7) \\
20(35.1)\end{array}$ & $\begin{array}{l}16(26.7) \\
17(29.8)\end{array}$ & $\begin{array}{c}8(13.3) \\
1(1.8)\end{array}$ & 0.42 & 1.00 & 0.031 & 0.44 \\
\hline
\end{tabular}

${ }^{1}$, Fisher's exact test. ${ }^{2}, 31$ low grade DCIS, 9 intermediate grade DCIS, 1 high grade DCIS. ${ }^{3}, 3$ patients missing. ${ }^{4}, 24$ patients missing.

The presence of ADH only in specimens with microcalcifications resulted in a statistically significant lower chance of upgrading the lesion to IC ( $p$-value: 0.031 ).

Moreover, by using patients' characteristics which were statistically significant at the univariate analysis as independent variables, multivariate analysis showed a correlation between the removal of the lesion, BIRADS and age, with the probability of ADH upgrading at the subsequent surgical excision (Table 3).

Table 3. Multivariate analysis considering the upgrade from ADH to either DCIS or invasive disease as the outcome and patients' characteristics resulting as statistically significant at univariate analysis $(p<0.05)$ as independent variables.

\begin{tabular}{|c|c|c|c|c|}
\hline \multirow{2}{*}{ Variables } & \multirow{2}{*}{$\begin{array}{c}\text { Upgrade to Carcinoma In Situ or Invasive } \\
\text { Carcinoma/Tot }(\%)\end{array}$} & \multicolumn{3}{|c|}{ Multivariate Analysis } \\
\hline & & OR & $95 \%$ CI & $p$-Value \\
\hline Overall & $52 / 138(37.7)$ & & & \\
\hline \multicolumn{5}{|l|}{ Age at the biopsy (years) } \\
\hline$<50$ & $16 / 58(27.6)$ & & & \\
\hline $50+$ & $36 / 80(45.0)$ & 2.53 & $1.11-5.80$ & 0.028 \\
\hline \multicolumn{5}{|l|}{ Size of the lesion (mm) } \\
\hline$\leq 15$ & $24 / 86(27.9)$ & & & \\
\hline$>15$ & $28 / 52(53.8)$ & 1.82 & $0.78-4.26$ & 0.17 \\
\hline \multicolumn{5}{|c|}{ BIRADS classification of the lesion } \\
\hline $3-4 a$ & $10 / 57(17.5)$ & & & \\
\hline $4 b-4 c-5$ & $42 / 81(51.9)$ & 4.17 & $1.78-9.79$ & 0.001 \\
\hline \multicolumn{5}{|c|}{ Residual lesion at the biopsy } \\
\hline No & $15 / 66(22.7)$ & & & \\
\hline Yes & $37 / 72(51.4)$ & 3.02 & $1.27-7.22$ & 0.013 \\
\hline
\end{tabular}

Note 1. Only variables with $p<0.05$ at univariate analysis were included in this analysis. Note 2 . The 3 patients with missing value of

"Residual lesion at the biopsy" were excluded from this analysis. OR: odds ratio; CI: confidence interval. 
According to this multivariate logistic regression, the predicted probabilities of upgrading the lesion (to in situ or invasive carcinoma) at surgical excision were calculated (Table 4).

Table 4. Predicted probabilities of the upgrade from ADH to either DCIS or invasive disease, according to the multivariate logistic regression model.

\begin{tabular}{|c|c|c|c|c|}
\hline $\begin{array}{c}\text { Age at the } \\
\text { Biopsy (Years) }\end{array}$ & $\begin{array}{l}\text { Size of the } \\
\text { Lesion (mm) }\end{array}$ & $\begin{array}{c}\text { BIRADS } \\
\text { Classification of } \\
\text { the Lesion }\end{array}$ & $\begin{array}{c}\text { Residual Lesion at } \\
\text { the Biopsy }\end{array}$ & Probability $(95 \%$ CI) \\
\hline \multirow[t]{8}{*}{$<50$} & $\leq 15$ & $3-4 a$ & No & $0.06(0.02-0.15)$ \\
\hline & & & Yes & $0.15(0.06-0.33)$ \\
\hline & & $4 b-4 c-5$ & No & $0.20(0.09-0.38)$ \\
\hline & & & Yes & $0.42(0.24-0.64)$ \\
\hline & $>15$ & $3-4 a$ & No & $0.10(0.03-0.27)$ \\
\hline & & & Yes & $0.24(0.11-0.46)$ \\
\hline & & $4 b-4 c-5$ & No & $0.31(0.13-0.58)$ \\
\hline & & & Yes & $0.57(0.37-0.75)$ \\
\hline \multirow[t]{8}{*}{$50+$} & $\leq 15$ & $3-4 a$ & No & $0.13(0.06-0.26)$ \\
\hline & & & Yes & $0.31(0.14-0.55)$ \\
\hline & & $4 b-4 c-5$ & No & $0.38(0.23-0.56)$ \\
\hline & & & Yes & $0.65(0.44-0.81)$ \\
\hline & $>15$ & $3-4 a$ & No & $0.21(0.08-0.45)$ \\
\hline & & & Yes & $0.45(0.24-0.68)$ \\
\hline & & $4 b-4 c-5$ & No & $0.53(0.30-0.75)$ \\
\hline & & & Yes & $0.77(0.61-0.88)$ \\
\hline
\end{tabular}

$45 / 141$ patients $(31.9 \%)$ were lost to follow up and not included in the statistical analysis. We found no significant correlation between the loss of patients to follow up and the prognostic variables (Figures 3 and 4).

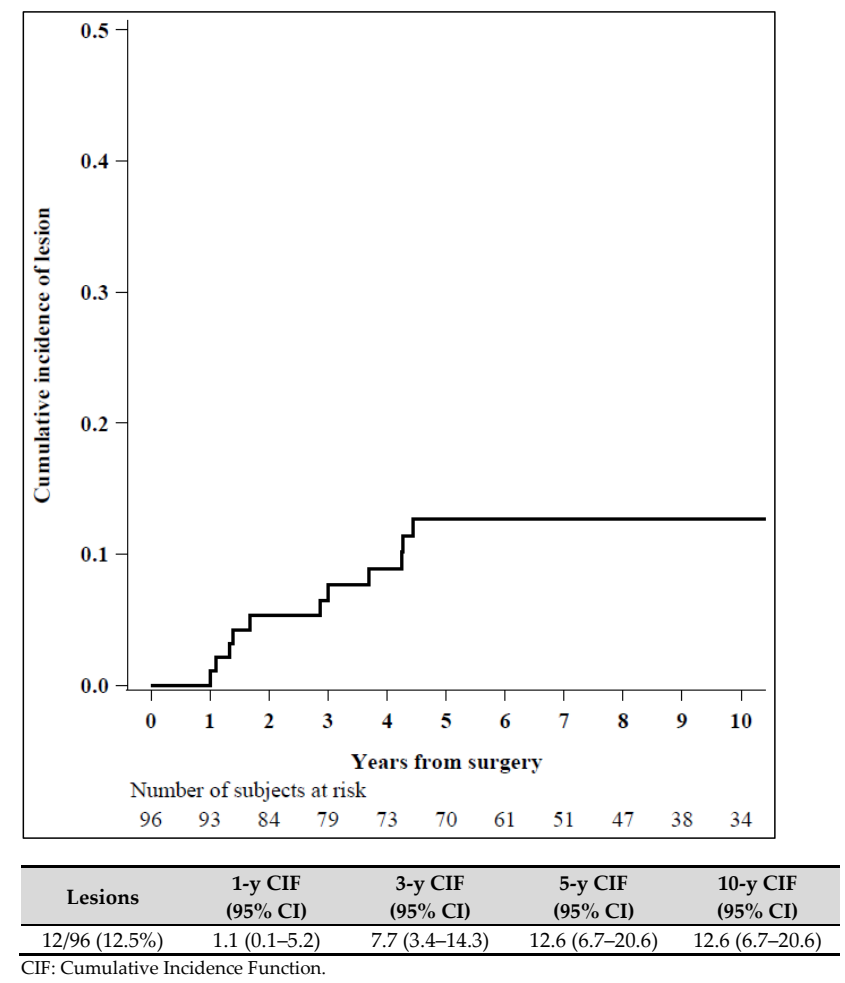

Figure 3. Cumulative incidence of lesion $(\mathrm{N}=96)$. 


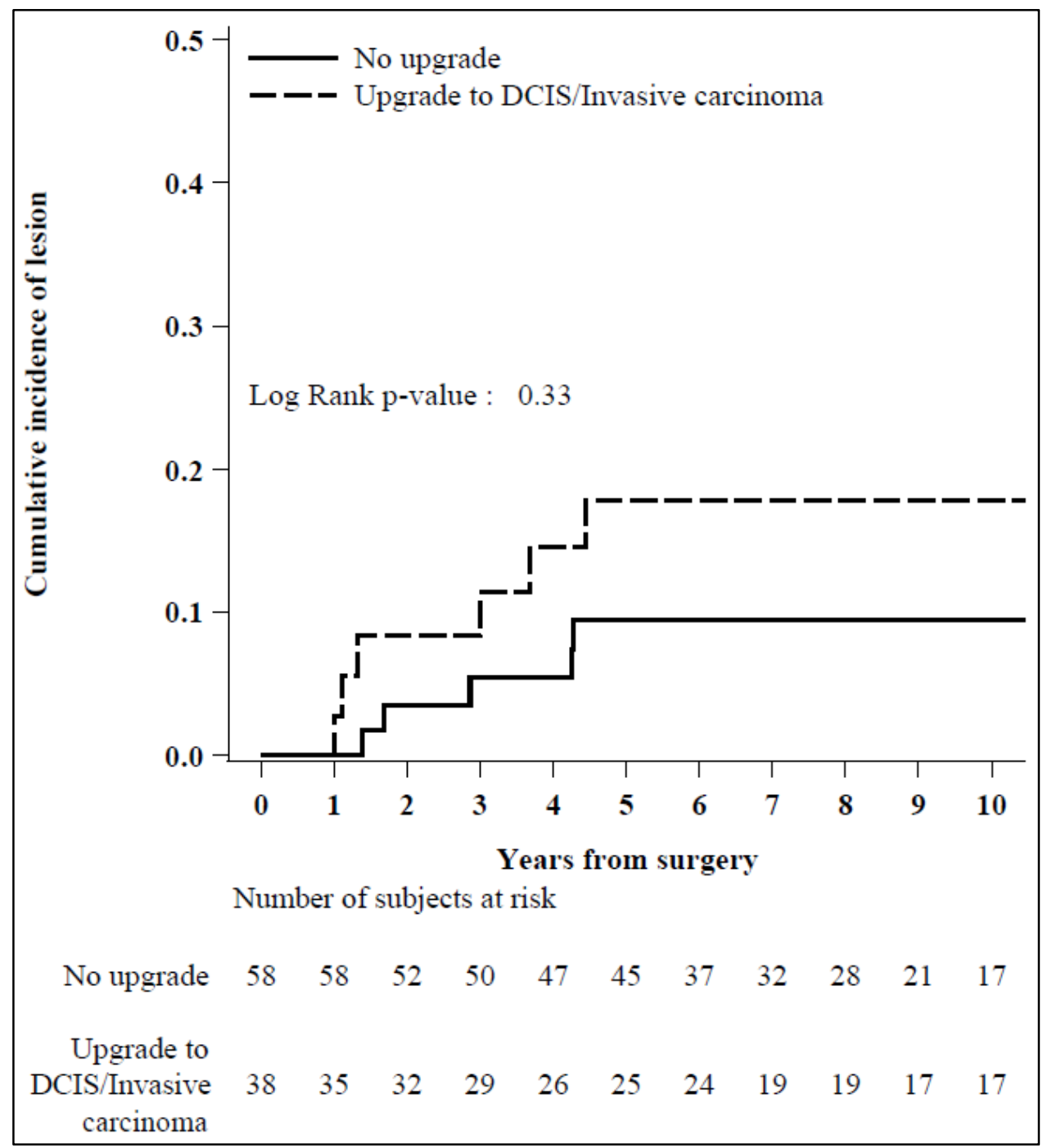

\begin{tabular}{cccccc}
\hline $\begin{array}{c}\text { Upgrade to } \\
\text { DCIS/Invasive } \\
\text { Carcinoma }\end{array}$ & Lesions & $\begin{array}{c}\mathbf{1 - y} \text { CIF } \\
\mathbf{( 9 5 \%} \mathbf{C I})\end{array}$ & $\begin{array}{c}\text { 3-y CIF } \\
\mathbf{( 9 5 \%} \mathbf{C I})\end{array}$ & $\begin{array}{c}\mathbf{5 - y} \text { CIF } \\
\mathbf{( 9 5 \% ~ C I ) ~}\end{array}$ & $\begin{array}{c}\mathbf{1 0 - y} \text { CIF } \\
\mathbf{( 9 5 \%} \text { CI) }\end{array}$ \\
\hline No & $6 / 58(10.3 \%)$ & 0.0 & $5.4(1.4-13.6)$ & $9.4(3.4-19.2)$ & $9.4(3.4-19.2)$ \\
Yes & $6 / 38(15.8 \%)$ & $2.8(0.2-12.6)$ & $11.4(3.5-24.4)$ & $17.8(7.1-32.6)$ & $17.8(7.1-32.6)$ \\
\hline
\end{tabular}

Figure 4. Cumulative incidence of lesion by upgrade to carcinoma in situ or invasive carcinoma $(\mathrm{N}=96)$.

Finally, we observed that $12 / 96$ patients (12.5\%) presented a breast lesion during the follow up period (we excluded in the analysis 45 patients lost to follow up). Specifically, we observed 4 cases of low grade DCIS, 1 case of intermediate grade DCIS, 1 case of high grade DCIS, 3 cases of atypical lobular hyperplasia and 3 cases of IC. The median time from surgery to the finding of breast lesion at follow up was 2.9 years. The overall median time of follow up was 7.6 years (4.3-11.1).

Interestingly, considering all the 12 patients developing a breast lesion during the follow up period, 6 of them had already been upgraded at initial surgical excision ( 5 cases of low grade DCIS and 1 case of IC).

Finally, we did not find any significant association between patients' characteristics and incidence of breast lesions (univariate analysis) during follow up following surgery for ADH (Table 5). 
Table 5. Association between patients' characteristics and incidence of lesion (univariate analysis) $(\mathrm{N}=96)$.

\begin{tabular}{|c|c|c|c|c|c|}
\hline Variable & $\mathbf{N}$ & Lesions & HR & $95 \% \mathrm{CI}$ & $p$-Value \\
\hline \multicolumn{6}{|l|}{ Age at the biopsy (year) } \\
\hline$<50$ & 46 & 5 & & & \\
\hline $50+$ & 50 & 7 & 1.25 & $0.40-3.97$ & 0.70 \\
\hline \multicolumn{6}{|l|}{ Size of the lesion (mm) } \\
\hline$\leq 15$ & 60 & 6 & & & \\
\hline$>15$ & 36 & 6 & 1.81 & $0.58-5.66$ & 0.30 \\
\hline \multicolumn{6}{|l|}{ BIRADS classification of the lesion } \\
\hline $3-4 a$ & 44 & 4 & & & \\
\hline $4 b-4 c-5$ & 52 & 8 & 1.63 & $0.49-5.46$ & 0.42 \\
\hline \multicolumn{6}{|l|}{ Number of cores } \\
\hline$<10$ & 32 & 3 & & & \\
\hline$\geq 10$ & 64 & 9 & 1.23 & $0.33-4.60$ & 0.75 \\
\hline \multicolumn{6}{|l|}{ Imaging findings } \\
\hline Microcalcifications & 82 & 11 & & & \\
\hline Nodule/Nodule with micro & 14 & 1 & 0.60 & $0.08-4.63$ & 0.62 \\
\hline \multicolumn{6}{|l|}{ Residual lesion at biopsy } \\
\hline No & 49 & 4 & & & \\
\hline Yes & 47 & 8 & 2.34 & $0.70-7.78$ & 0.17 \\
\hline \multicolumn{6}{|l|}{ ADH only in cores with micro } \\
\hline No & 37 & 4 & & & \\
\hline Yes & 42 & 7 & 1.58 & $0.46-5.42$ & 0.47 \\
\hline Missing & 17 & 1 & & & \\
\hline \multicolumn{6}{|l|}{ Upgrade to DCIS/Invasive carcinoma } \\
\hline No upgrade & 58 & 6 & & & \\
\hline Upgrade & 38 & 6 & 1.74 & $0.56-5.41$ & 0.34 \\
\hline
\end{tabular}

\section{Discussion}

In recent decades the widespread use of image-guided biopsy devices has increased the diagnosis of $\mathrm{ADH}$, with a current observed incidence ranging from $1 \%$ to $10 \%[22,23]$. Consequently, clinical awareness of lesion characteristics and clinical significance have gained broader attention [23-28]; however, their management is still under debate. The Second International Consensus Conference on breast lesions of uncertain malignant potential states that surgery should be performed [15].

Amorphous microcalcifications are the most common imaging presentation of ADH [28-30]. Our findings confirm these data, with microcalcifications being the most common form of presentation in patients diagnosed with $\mathrm{ADH}$ : most biopsies were therefore performed under stereotactic guidance. While ADH has no specific ultrasonographic findings, in our study it frequently appeared as a nodule by ultrasonography.

ADH diagnosed by breast biopsy is associated with a high incidence of DCIS and IC at the subsequent surgical excision [7,10,30-32], as demonstrated by recent metanalyses $[33,34]$ reporting an upgrade rate of $9 \%$ for invasive carcinoma.

Our study is in line with these results: on surgical excision, we observed an upgrade rate of $7.8 \%$ to IC and of $29.1 \%$ to DCIS. Most of the upgrade cases (22\%) were represented by low grade DCIS: this is probably associated with the ADH definition and the monocentric type of this study assuming the intra-observer reproducibility.

This result is even more important considering that follow-up, rather than surgery, is now proposed even in low-grade DCIS [35].

Our efforts should be focused, primarily, on trying to reduce the percentage of upgrade to IC. In our study the percentage of the pooled upstaging $(7.8 \%)$ to IC is still too high to justify follow-up as a choice rather than surgery: according to the Breast Imaging Reporting and Data System, follow-up would be justified by an upgrade rate lower than $2 \%$ to IC [20]. Many studies have tried to identify features that may reduce the upgrade rate to IC and 
guide the clinical approach based on histopathological and imaging characteristics [36-38]. However, the upgrade to IC remains non-negligible and, according to Second International Consensus Conference recommendations [15], "surveillance can be justified only in special situations after discussion at the multidisciplinary meeting".

In our study, we found a statistically significant reduction of the upgrade rate considering the following parameters: age of the patients, lesion size, BIRADs and the complete macroscopical removal of the lesion by VABB, as already documented for the upgrading rate of DCIS to IC [39]. Moreover, the upgrade rate to IC is significantly reduced when $\mathrm{ADH}$ is found only in specimens showing microcalcifications.

Multivariate logistic regression analysis showed that, considering all these parameters, the pooled percentage of upgrade at the surgical excision is considerably reduced. Moreover, in our work we highlight the importance of follow up, even after surgery, due to the non-negligible possibility of finding recurrent breast lesions. The importance of this result, in our study, is unfortunately limited by the high number of patients lost to follow up.

\section{Conclusions}

The overall upgrade rate of ADH to DCIS or IC is high, and surgery should be recommended. However, ADH cases should always be discussed in a multidisciplinary meeting in order to identify which parameters could be valuable to establish a risk score useful to distinguish patients that could be offered a short-term follow-up rather than immediate surgery. On the other hand, these conclusions are constrained by the retrospective nature of the study which represents the main limitation, along with the small number of ADH cases and the significant number of patients lost to follow-up.

Future studies involving multiple centers with different practices are needed to better describe the natural history of ADH and avoid unnecessary surgical interventions. A hypothetical trial specifically designed for ADH may randomize patients to surgical excision vs active surveillance or active surveillance combined with endocrine treatment (e.g., low dose tamoxifen), based on the results already achieved by other studies [40,41].

Author Contributions: Conceptualization, L.N. and A.L.; methodology, A.C.B., R.D.S., G.M. and O.P.; software, O.P., M.M. and G.L.; validation, F.A., M.G.M. and E.C.; formal analysis, S.F. and V.B.; investigation, R.D.S., M.L. and G.L.; resources, A.L., M.M. and M.L.; data curation, M.L., S.F. and V.B.; writing-original draft preparation, L.N. and E.C.; writing—review and editing, F.A. and M.G.M.; visualization, A.C.B. and E.C.; supervision, F.A. and M.G.M.; project administration, G.M. and E.C. All authors have read and agreed to the published version of the manuscript.

Funding: This research received no external funding.

Institutional Review Board Statement: The study was conducted according to the guidelines of the Declaration of Helsinki and approved on 14th of April 2020, by the Ethics Committee of European Institute of Oncology (IEO, protocol code UID 2300 14/4/2020).

Informed Consent Statement: Informed consent was obtained from all subjects involved in the study.

Data Availability Statement: Data sharing not applicable.

Conflicts of Interest: The authors declare no conflict of interest.

\section{References}

1. Mastropasqua, M.G.; Viale, G. Clinical and pathological assessment of high-risk ductal and lobular breast lesions: What surgeons must know. Eur. J. Surg. Oncol. 2017, 43, 278-284. [CrossRef]

2. Clauser, P.; Marino, M.A.; Baltzer, P.A.T.; Bazzocchi, M.; Zuiani, C. Management of atypical lobular hyperplasia, atypical ductal hyperplasia, and lobular carcinoma in situ. Expert Rev. Anticancer Ther. 2016, 16, 335-346. [CrossRef]

3. Peña, A.; Shah, S.S.; Fazzio, R.T.; Hoskin, T.L.; Brahmbhatt, R.D.; Hieken, T.J.; Jakub, J.W.; Boughey, J.C.; Visscher, D.W.; Degnim, A.C. Multivariate model to identify women at low risk of cancer upgrade after a core needle biopsy diagnosis of atypical ductal hyperplasia. Breast Cancer Res. Treat. 2017, 164, 295-304. [CrossRef] [PubMed]

4. Silvera, S.A.N.; Rohan, T.E. Benign proliferative epithelial disorders of the breast: A review of the epidemiologic evidence. Breast Cancer Res. Treat. 2008, 110, 397-409. [CrossRef] 
5. Racz, J.M.; Carter, J.M.; Degnim, A.C. Lobular Neoplasia and Atypical Ductal Hyperplasia on Core Biopsy: Current Surgical Management Recommendations. Ann. Surg. Oncol. 2017, 24, 2848-2854. [CrossRef] [PubMed]

6. Degnim, A.C.; Visscher, D.W.; Berman, H.K.; Frost, M.H.; Sellers, T.A.; Vierkant, R.A.; Maloney, S.D.; Pankratz, V.S.; de Groen, P.C.; Lingle, W.L.; et al. Stratification of breast cancer risk in women with atypia: A mayo cohort study. J. Clin. Oncol. 2007, 25, 2671-2677. [CrossRef] [PubMed]

7. Hartmann, L.C.; Degnim, A.C.; Santen, R.J.; Dupont, W.D.; Ghosh, K. Atypical Hyperplasia of the Breast-Risk Assessment and Management Options. N. Eng. J. Med. 2015, 372, 78-89. [CrossRef]

8. Murray, M. Pathologic High-risk Lesions, Diagnosis and Management. Clin. Obstet. Gynecol. 2016, 59, 727-732. [CrossRef] [PubMed]

9. Latronico, A.; Nicosia, L.; Faggian, A.; Abbate, F.; Penco, S.; Bozzini, A.; Cannataci, C.; Mazzarol, G.; Cassano, E. Atypical ductal hyperplasia: Our experience in the management and long term clinical follow-up in 71 patients. Breast 2018, 37, 1-5. [CrossRef]

10. Renshaw, A.A.; Gould, E.W. Long term clinical follow-up of atypical ductal hyperplasia and lobular carcinoma in situ in breast core needle biopsies. Pathology 2016, 48, 25-29. [CrossRef] [PubMed]

11. Goldacre, M.J.; Abisgold, J.D.; Yeates, D.G.R.; Vessey, M.P. Benign breast disease and subsequent breast cancer: English record linkage studies. J. Public Health 2010, 32, 565-571. [CrossRef] [PubMed]

12. Page, D.L.; Schuyler, P.A.; Dupont, W.D.; Jensen, R.A.; Plummer, W.D., Jr.; Simpson, J.F. Atypical lobular hyperplasia as a unilateral predictor of breast cancer risk: A retrospective cohort study. Lancet 2003, 361, 125-129. [CrossRef]

13. Kader, T.; Hill, P.; Rakha, E.A.; Campbell, I.G.; Gorringe, K.L. Atypical ductal hyperplasia: Update on diagnosis, management, and molecular landscape. Breast Cancer Res. 2018, 20, 1-11. [CrossRef]

14. Schiaffino, S.; Massone, E.; Gristina, L.; Fregatti, P.; Rescinito, G.; Villa, A.; Friedman, D.; Calabrese, M. Vacuum assisted breast biopsy (VAB) excision of subcentimeter microcalcifications as an alternative to open biopsy for atypical ductal hyperplasia. Br. $J$. Radiol. 2018, 91, 20180003. [CrossRef] [PubMed]

15. Rageth, C.J.; O’Flynn, E.A.M.; Pinker, K.; Kubik-Huch, R.A.; Mundinger, A.; Decker, T.; Tausch, C.; Dammann, F.; Baltzer, P.A.; Fallenberg, E.M.; et al. Second International Consensus Conference on lesions of uncertain malignant potential in the breast (B3 lesions). Breast Cancer Res. Treat. 2019, 174, 279-296. [CrossRef]

16. Degnim, A.C.; King, T.A. Surgical management of high-risk breast lesions. Surg. Clin. N. Am. 2013, 93, 329-340. [CrossRef] [PubMed]

17. Morrow, M.; Schnitt, S.J.; Norton, L. Current management of lesions associated with an increased risk of breast cancer. Nat. Rev. Clin. Oncol. 2015, 12, 227-238. [CrossRef] [PubMed]

18. Jackman, R.J.; Birdwell, R.L.; Ikeda, D.M. Atypical ductal hyperplasia: Can some lesions be defined as probably benign after stereotactic 11-gauge vacuum-assisted biopsy, eliminating the recommendation for surgical excision? Radiology 2002, 224, 548-554. [CrossRef]

19. Travade, A.; Isnard, A.; Bouchet, F.; Bagard, C. Non-palpable breast lesions and core needle biopsy with mammotome 11G: Is surgery required in patients with atypical ductal hyperplasia? J. Radiol. 2006, 87, 307-310. [CrossRef]

20. D'Orsi, C.J.; Sickles, E.A.; Mendelson, E.B.; Morris, E.A. ACR BI-RADS ${ }^{\circledR}$ Atlas, Breast Imaging Reporting and Data System; American College of Radiology: Reston, VA, USA, 2013; ISBN 155903016X.

21. Ellis, I.O.; Humphreys, S.; Michell, M.; Pinder, S.E.; Wells, C.A.; Zakhour, H.D. Best Practice No 179. Guidelines for breast needle core biopsy handling and reporting in breast screening assessment. J. Clin. Pathol. 2004, 57, 897-902. [CrossRef] [PubMed]

22. Philpotts, L.E.; Shaheen, N.A.; Jain, K.S.; Carter, D.L.; Lee, C.H. Uncommon high-risk lesions of the breast diagnosed at stereotactic core-needle biopsy: Clinical importance. Radiology 2000, 216, 831-837. [CrossRef]

23. Degnim, A.C.; Winham, S.J.; Frank, R.D.; Pankratz, S.; Dupont, W.D.; Vierkant, R.A.; Frost, M.H.; Hoskin, T.L.; Vachon, C.M.; Ghosh, K.; et al. Model for Predicting Breast Cancer Risk in Women with Atypical Hyperplasia. J. Clin. Oncol. 2018, 36, 1840-1846. [CrossRef]

24. Menes, T.S.; Kerlikowske, K.; Lange, J.; Jaffer, S.; Rosenberg, R.; Miglioretti, D. Subsequent Breast Cancer Risk Following Diagnosis of Atypical Ductal Hyperplasia on Needle Biopsy. JAMA Oncol. 2017, 3, 36-41. [CrossRef]

25. Subhawong, A.P.; Subhawong, T.K.; Khouri, N.; Tsangaris, T.; Nassar, H. Incidental minimal atypical lobular hyperplasia on core needle biopsy: Correlation with findings on follow-up excision. Am. J. Surg. Pathol. 2010, 34, 822-828. [CrossRef] [PubMed]

26. Berg, W.A. Image-guided breast biopsy and management of high-risk lesions. Radiol. Clin. N. Am. 2004, 42, 935-946. [CrossRef] [PubMed]

27. McGhan, L.J.; Pockaj, B.A.; Wasif, N.; Giurescu, M.E.; McCullough, A.E.; Gray, R.J. Atypical Ductal Hyperplasia on Core Biopsy: An Automatic Trigger for Excisional Biopsy? Ann. Surg. Oncol. 2012, 19, 3264-3269. [CrossRef]

28. Arthur, R.; Wang, Y.; Ye, K.; Glass, A.G.; Ginsberg, M.; Loudig, O.; Rohan, T. Association between lifestyle, menstrual/reproductive history, and histological factors and risk of breast cancer in women biopsied for benign breast disease. Breast Cancer Res. Treat. 2017, 165, 623-6431. [CrossRef] [PubMed]

29. Georgian-Smith, D.; Lawton, T.J. Controversies on the management of high-risk lesions at core biopsy from a radiology/pathology perspective. Radiol. Clin. N. Am. 2010, 48, 999-1012. [CrossRef] [PubMed]

30. Ching, J.G.; Brem, R.F. Breast lesions detected via molecular breast imaging: Physiological parameters affecting interpretation. Acad. Radiol. 2018, 25, 1568-1576. [CrossRef] 
31. Simpson, J.F. Update on atypical epithelial hyperplasia and ductal carcinoma in situ. Pathology 2009, 41, 36-39. [CrossRef] [PubMed]

32. Rudin, A.V.; Hoskin, T.L.; Fahy, A.; Farrell, A.M.; Nassar, A.; Ghosh, K.; Degnim, A.C. Flat Epithelial Atypia on Core Biopsy and Upgrade to Cancer: A Systematic Review and Meta-Analysis. Ann. Surg. Oncol. 2017, 24, 3549-3558. [CrossRef]

33. Dyrstad, S.W.; Yan, Y.; Fowler, A.M.; Colditz, G.A. Breast cancer risk associated with benign breast disease: Systematic review and meta-analysis. Breast Cancer Res. Treat. 2015, 149, 569-575. [CrossRef]

34. Schiaffino, S.; Calabrese, M.; Melani, E.F.; Trimboli, R.M.; Cozzi, A.; Carbonaro, L.A.; Di Leo, G.; Sardanelli, F. Upgrade Rate of Percutaneously Diagnosed Pure Atypical Ductal Hyperplasia: Systematic Review and Meta-Analysis of 6458 Lesions. Radiology 2020, 294, 76-86. [CrossRef] [PubMed]

35. Kanbayashi, C.; Thompson, A.M.; Hwang, E.S.; Partridge, A.H.; Rea, D.W.; Wesseling, J.; Shien, T.; Mizutani, T.; Shibata, T.; Iwata, $\mathrm{H}$. The international collaboration of active surveillance trials for low-risk DCIS (LORIS, LORD, COMET, LORETTA). J. Clin. Oncol. 2019, 37 (Suppl. S15), TPS603. [CrossRef]

36. Deshaies, I.; Provencher, L.; Jacob, S.; Cote, G.; Robert, J.; Desbiens, C.; Poirier, B.; Hogue, J.C.; Vachon, E.; Diorio, C. Factors associated with upgrading to malignancy at surgery of atypical ductal hyperplasia diagnosed on core biopsy. Breast 2011, 20, 50-55. [CrossRef]

37. Esserman, L.E.; Lamea, L.; Tanev, S.; Poppiti, R. Should the extent of lobular neoplasia on core biopsy influence the decision for excision? Breast J. 2007, 13, 55-61. [CrossRef] [PubMed]

38. Chen, L.Y.; Hu, J.; Tsang, J.Y.S.; Lee, M.A.; Ni, Y.B.; Chan, S.K.; Tse, G.M.K. Diagnostic upgrade of atypical ductal hyperplasia of the breast based on evaluation of histopathological features and calcification on core needle biopsy. Histopathology 2019, 75, 320-328. [CrossRef] [PubMed]

39. Nicosia, L.; di Giulio, G.; Bozzini, A.C.; Fanizza, M.; Ballati, F.; Rotili, A.; Lazzeroni, M.; Latronico, A.; Abbate, F.; Renne, G.; et al. Complete Removal of the Lesion as a Guidance in the Management of Patients with Breast Ductal Carcinoma In Situ. Cancers 2021, 13, 868. [CrossRef]

40. Khoury, T.; Jabbour, N.; Peng, X.; Yan, L.; Quinn, M. Atypical Ductal Hyperplasia and Those Bordering on Ductal Carcinoma In Situ Should Be Included in the Active Surveillance Clinical Trials. Am. J. Clin. Pathol. 2020, 153, 131-138. [CrossRef] [PubMed]

41. Lazzeroni, M.; DeCensi, A. De-Escalating Treatment of Low-Risk Breast Ductal Carcinoma In Situ. J. Clin. Oncol. 2020, 38, 1252-1254. [CrossRef] 